\title{
Subjectivity and Sexuality Production in Women Living With HIV/Aids: a Sociopoetic Production
}

\author{
Arisa Nara Saldanha de Almeida ${ }^{1}$ \\ Lia Carneiro Silveira ${ }^{2}$ \\ Maria Rocineide Ferreira da Silva ${ }^{3}$ \\ Michell Ângelo Marques Araújo ${ }^{4}$ \\ Terezinha Andrade Guimarães ${ }^{5}$
}

\begin{abstract}
The study aims to apprehend the subjectivity production possibilities concerning sexuality in a group of women living with HIV/aids, based on the sociopoetic method. The subjects were nine women with HIV/aids attended at the public referral hospital for infectious diseases in Fortaleza-CE. The results appoint that sexuality appears in several dimensions: in the sexual act, in knowing their own body, in professional accomplishment, in feelings of desire and love, besides the feeling of freedom. We concluded that sexuality is present in the individual's totality; it is not limited to the sexual act, but goes much further and is characterized as a dynamic reality
\end{abstract}

Descriptors: Sexuality; Women; Acquired Immunodeficiency Syndrome.

\footnotetext{
${ }^{1}$ RN, Master's Student, Universidade Estadual do Ceará, CE, Brazil. Scholarship holder CAPES. E-mail: arisinha2003@yahoo.com.br. ${ }^{2}$ RN, Ph.D. in Nursing, Faculty, Universidade Estadual do Ceará, CE, Brazil. E-mail: silveiralia@gmail.com.

${ }^{3}$ RN, Doctoral Student in Public Health, Universidade Estadual do Ceará, CE, Brazil. Faculty, Universidade Estadual do Ceará, CE, Brazil. E-mail: rocineideferreira@gmail.com.

${ }^{4}$ RN, Doctoral Student in Nursing, Universidade Federal do Ceará, CE, Brazil. Faculty, Faculdade Católica Rainha do Sertão, CE, Brazil. E-mail: micenf@yahoo.com.br.

${ }^{5}$ Psychologist, M.Sc. in Public Health, Hospital São José de Doenças Infecciosas, CE, Brazil. E-mail: terezinha_andrade@terra.com.br.
} 


\title{
Produção de subjetividade e sexualidade em mulheres vivendo com o HIV/Aids: uma produção sociopoética
}

O objetivo deste estudo foi apreender as possibilidades de produção de subjetividade acerca da sexualidade em um grupo de mulheres vivendo com o HIV/AIDS, a partir do método da sociopoética. Os sujeitos foram nove mulheres com HIV/AIDS assistidas no hospital público de referência para doenças infecciosas de Fortaleza, CE. Os resultados apontam que a sexualidade aparece em várias dimensões: no ato sexual, no conhecer o próprio corpo, na realização profissional, nos sentimentos de desejo e amor, além do sentimento de liberdade. Conclui-se que a sexualidade se encontra na totalidade do indivíduo, ela não se limita à questão do ato sexual, vai muito mais além e se configura como realidade dinâmica.

Descritores: Sexualidade; Mulheres; Síndrome de Imunodeficiência Adquirida.

\section{Producción de subjetividad y sexualidad en mujeres viviendo con el VIH/Sida: una producción socio-poética}

\begin{abstract}
El objetivo de este estudio fue aprender las posibilidades de producción de subjetividad acerca de la sexualidad en un grupo de mujeres viviendo con el HIV/SIDA, a partir del método de la socio-poética. Los sujetos fueron nueve mujeres con HIV/SIDA asistidas en un hospital público de referencia para enfermedades infecciosas de Fortaleza, CE. Los resultados apuntan que la sexualidad aparece en varias dimensiones: en el acto sexual, en el conocer el propio cuerpo, en la realización profesional, en los sentimientos de deseo y amor, además del sentimiento de libertad. Se concluye que la sexualidad se encuentra en la totalidad del individuo, ella no se limita al acto sexual, va mucho más allá y se configura como realidad dinámica.
\end{abstract}

Descriptores: Sexualidad; Mujeres; Síndrome de Inmunodeficiencia Adquirida.

\section{Introduction}

Increasing contamination by the Aids virus has affected women more and more, from low income and education levels, of reproductive age and with heterosexual behavior, revealing that "there are no more risk populations, but a set of factors that make people catch the virus"(1). These factors are related to subjective and objective structural problems, such as poverty, violence, low education level, gender inequity, lack of access to health services, among others.

Besides these macro stratifications, subjective micro-models can also be perceived, which start to accompany the imaginary of aids: anguish and fear of proximity with the unknown; difficulty to decrystalize established territories; as well as the need to deal with one's own sexuality.

Sexuality is a dimension of human life which we know is profoundly determined by the sociocultural context it happens in ${ }^{(2)}$. Moreover, it should be highlighted that it is not based on a natural and innate order, but is created and constructed through the sedimentation of successive identifications at different levels (symbolic, imaginary and fantasmatic), resulting from this subject's encounters with the significant ${ }^{(3)}$.

In this context, the way of dealing with life and sexuality takes on different connotations in people living with HIV/aids. It is fundamental to get to know what the experiences of women with HIV/aids have in common and what is specific to each, in order to cope with the difficulties deriving from the disease.

Hence, considering the subjectivity production in women living with HIV/aids, it needs to be questioned: how do these women reconstruct their subjectivity, their sexuality and their singularization process in living with aids? 
Thus, this research aims to apprehend the subjectivity productions and new concepts of sexuality in a group of women living with HIV/aids, based on the sociopoetic method.

\section{Building the way: the sociopoetic method}

This is a qualitative research. The researcher's goal is not to solve an empirical questions (although practical proposals can emerge), but to examine the normative "truths" that permeate the historical context, playing a role of deconstructing what exists and making room for new productions based on critical conscience by the participants as well as the researcher ${ }^{(4)}$.

This conceptual outline brings us to a concern with how to address subjectivity production in the field of the intersection between sexuality and Aids and to the search for a method that would allow us to dive into this method without paralyzing it, however. Sociopoetics offers us the instruments and techniques needed to put our objective in practice.

Sociopoetics is a research approach that intends to critically analyze the social reality and makes it possible to work with the intersections between the desires and powers active in social life ${ }^{(5)}$. To make this possible, facilitators are responsible for using devices, that is, structures or gimmicks that favor the emergence of innovations, differences, singularities. These devices can be characterized by a fact, a person, a time, an object or a task that intervenes during the research, permitting the multiplication of already established answers and reactions towards a given situation.

\section{Research phases}

The method proposed by sociopoetics and which we will follow in this research is that of the group-researcher, whose proposal values the political aspect of knowledge production in health by promoting a new relationship of strengths and reverting the model based on the verticality of a researcher who interprets the subjects' statements, imposing his/her word as final. At this moment, people who used to be subjugated as objects of medical knowledge become subjects in knowledge production about the health-disease process and their autonomy is valued $^{(6)}$. The research phases are detailed below:

Negotiation - the study site chosen was a public referral hospital for infectious diseases in Fortaleza-CE. The research subjects were women with HIV attended at the same institution. Inclusion criteria were: being attended at the HIV/aids counseling outpatient clinic of the study institution in May 2007; HIV seropositive status; living in Fortaleza; being at least 18 years of age and available to participate in the research. A negotiation workshop was held on 06/15/2007 with all women who were contacted, where we presented the research proposal and identified possible candidates interested in participating. At the end, nine women accepted to participate in the research.

Data production - this production moment represents a rupture with established research practices, in which the research subject is explored and alienated as a mere research data provider. That is why sociopoetic research refers to "data production" instead of "data collection". We believe that knowledge is gradually constructed in a collective process between the researcher and the research subject(6). Data were produced in a workshop during which we used techniques/devices that allowed us to put the principles of sociopoetics in practice. The workshop started with a bodily preparation activity (relaxation) and, next, data production started, using the 'sexuality animal' technique, in which each co-researcher chooses an animal associated with sexuality. Then, each woman painted her animal on the canvas, followed by a discussion about the theme, aimed at recovering knowledge originating in reason, intuition and emotion. Statements were recorded and transcribed for the third research phase. The workshop took two hours.

Data analysis - at this moment too, the participation of the group-researcher is key to the process. This phase occurred in a specific workshop where the group performed the analysis, commenting on the produced data within the reference framework of their lives. Later, the primary investigator responsible for the research also performed individual analyses, using different angles. In this phase, the group's verbal production was analyzed according to the analysis technique sociopoetics proposes: classification, cross-sectional and philosophical analysis.

Participants were guaranteed anonymity and the right to cease their participation if they did not feel apt or sufficiently interested in the subject. The principles of resolution No 196/96 were complied with, which relates to research involving human beings. To guarantee respect for ethical premises, approval for the research was obtained from the research ethics committee at the study institution, under protocol No 005/2007 (CEP-HSJ).

\section{Presentation of categories: the sexuality animal}

Verbal data are first treated by categorizing the statements, attempting to identify key words, cutting 
and classifying data according to their relations of compossibility (Classification Analysis). At this moment, one can identify series and perceive how they are distributed. We attempted to organize the statements according to the themes that emerge from the group's own discourse. Next, we looked for convergences, divergences, oppositions and complementarities, resulting in the following categories: 1 - Feelings attributed to the relaxation; 2 - Meanings attributed to the sexuality animal; 3 - Meanings attributed to sexuality; 4 - Meanings attributed to HIV-positive status; 5 - Sexuality and Body; 6- Motherhood and HIV.

After categorizing the statements, cross-sectional analysis was performed, which attempts to connect what was separated in the earlier analysis, generally producing a more poetic text that aims to seek the relations between statements in the same category and between different categories. This moment is inspired by intuitive and fluid thinking, where we join excerpts from the groupresearcher's own discourse to create one single text. The original research text is presented next.

\section{Cross-sectional analysis - sexuality $x$ HIV, what a strange animal is that?}

The group's production started with relaxation, where different feelings were experienced, ranging from a pleasant moment to peace, childhood memories, reflections about life, and even memories of a longsuffering past. Amidst these emotions, not everybody managed to turn to the proposal to create the sexuality animal.

Everything that could be said at this moment was about a large and beautiful but (...) empty house. Life can be like that, large and empty, and then you need to seek help out there, find other people, help people who are suffering, get in a better mood. Otherwise one cannot bear the pain: the pain of being alone, the pain of an unbearable past that devastates the house like a large and dry tree. It is part of the story. The lack of affection can be the heaviest part of this past, or also a violent act like rape.

About affection, we can affirm that it is even more important than the sexual relation itself. Because sexuality is not only wild sex. It means feeling pleasure when doing anything, when being close to a person, it means talking, touching one another. It means having a person besides you who cares, who is concerned, who admires you. Some people flee from sex, do not feel any pleasure in the sexual relation, as sex is not just a calm and serene ocean. It can also be intense, so hot that it might scare you. It is an ocean filled with pleasure, the pleasure of a pleasant, complete woman.

This ocean can turn into torment when its waters mix with the waters of HIV. These waters are made of tears that turn you into a person who does not want to do anything, who does not like life. The discovery of HIV-positive status comes as a shock, overwhelming the person with negative feelings, doubts and fear. It is a light that is about to burn, it turns on and off, taking away the desire to live. At that moment, family support is essential. Many women, however, do not find this support, but prejudice from people who turn their back on them. What is important is that, over time, you manage to life your head and make plans for the future and live intensely.

Not everyone perceives HIV as the worst part though: the worst is to live with the memories of the past, things that hurt more than HIV. And, although this may seem contradictory, some even feel more feminine, more woman, more female after HIV than before it, releasing their sexuality to the full.

The relations between man and woman after the discovery of the virus are not easy either. A feeling of revolt, dislike, disgust comes up. Because it is difficult to be born as a woman, date, get involves and suddenly have a penis get into you and contaminate you with a virus. In this case, so many terrible things go through your head that you may never want to have sex again.

For many women, the feeling of rage is so big that they do not manage to forgive. How can your partner know about the existence of the virus but nevertheless not warn his wife? Many of them do not even accept that their wife suggests using a condom, as they think they are being betrayed. Women have to require this though, even if both partners are HIV-positive, even if it is midnight, they have to look for a condom and use it, as only people going through this disease know what it provokes.

The most feared effects of aids are the ones that appear on the body: the fear of getting ugly, skinny and losing one's hair. Vain women love to take care of their body and the effects of Aids may greatly affect their sexuality. After all, sexuality is not just sex: it means knowing your own body, it is, it is living the body. These are moments of accomplishments, in feelings of pleasure and love, in feeling well with oneself, in desire and pleasure to work. It is when you are free to choose.

Another issue that is difficult to deal with between sexuality and aids is motherhood. During pregnancy, women are very sensitive and, in this case, have to face 
the doubts, fears and uncertainties of HIV. Knowing that she is going to infect her baby and not the father, the man who put it in her, causes suffering. In short, living sexuality can mean playing the role of different animals: sexuality can be a loyal bird, which builds its nest and sets up a family. It can be sensitive and affectionate like an ewe or a cat (and why not a snake?). It can also be a strong cow, which takes care and feeds. It can also be a rabbit that, afraid of getting skinny, eats without stopping. But it can also be a butterfly, free to fly.

\section{Data discussion: philosophical analysis}

We will now present the philosophical analysis as proposed by the sociopoetic method. The knowledge the group produced is philosophical, as it favors the creation of new inquiries or new ways of problematizing life, leading to the creation of confections (neologism that joins concepts and affections) ${ }^{(5)}$. Hence, philosophical analysis is an exercise of sensitive listening to the group's discourse, trying to identify ideas that turn into confections. Moreover, this analysis offers the possibility of approximation between the knowledge produced by the group-research and theoretical-philosophical reflections by other authors or currents, seeking correlations and divergences.

When returning to the group-researcher's discourse, we identify the different confections produced about sexuality, that is, the new concepts that emerged about the theme. One of the confections highlighted was the big and empty house. This confection relates sexuality with the context of each subject's life history. That is, the meaning of life can be like this, big and empty. And, in this case, what is most unbearable are the memories of the past, traumatic events, experiences of deficiency and lack of affection. According to the group-researcher, these experiences cause irreparable traumas.

The countless narratives about child traumas correspond to a psychic reality instead of actual

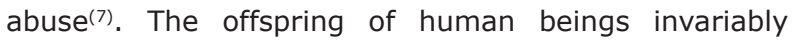
needs attention and care to survive. But this does not refer to physical care alone. These small subjects also present an unlimited demand for love. Exactly because this demand is unlimited, however, it can never be fully satisfied. Besides, the entire care the baby receives (such as the touch of maternal care for grooming) can be experienced as excessive and, as such, traumatic.

The book "O Corpo Educado: pedagogias da sexualidade"(8) [the Educated Body: pedagogies of sexuality] argues that, although the biological body is the site where sexuality takes place, it is more than simply the body. This book suggests that the most important organ in human beings is what lies between the ears. Hence, sexuality is as much about our beliefs, ideologies and imaginations as about our physical body. According to the same author, sexuality is modeled by two main concerns: our subjectivity (who and what we are) and society (with health, prosperity, growth and wellbeing for the population as a whole). These two are closely connected because the body and its potentials lie at the centre of both $^{(8)}$

The group-researcher also supports this broader idea of sexuality by affirming that sexuality means feeling pleasure about doing anything, about being close to someone, talking, touching.

Another confection identified in the group production is that of a Calm and intense ocean. This ocean is calm, as many women flee from sex and do not feel pleasure in sexual relations. But it is also intense, an ocean filled with pleasure, which becomes turbulent when joining with the waters of HIV. These waters are tears of people who, when confronted with HIV, become apathetic towards life. The discovery of HIV-positive status is overwhelmed by negative feelings, fear, doubts and death. Moreover, the worst effects of aids are revealed in the body: fear of getting skinny, getting ugly and losing one's hair.

The following feelings are mentioned with regard to the revelation of HIV: guilt, remorse, regret, revolt, fear, despair, suicide wish, denial to accept the diagnosis, rage, aggressiveness, sexual difficulties, loss of sexual desire. Hence, people living with HIV/Aids need to fight to defend life, their singularity and differences, and construct their citizenship of mortar, including sensitivity, affection, equality and solidarity(9-10).

This encounter with HIV some human beings experience is often manifested in feelings of anguish. This anguish present in HIV-positive patients is also related to the confrontation with the unknown, which reveals itself early in life and, when it is known, life will not continue ${ }^{(11)}$. Besides, social prejudice and the presence of death also contribute to this suffering. The text "Our attitude towards death" strengthens that we will never be sufficiently ready to accept death. In our unconscious, we are convinced of our immortality, as, in life, we are not able to think and talk about an experience we have never been through(12). In fact, we cannot imagine our own death and, whenever we try, we are still present as spectators.

Also, considering how the virus is transmitted, some women blocked their sexual desire and are not 
able to feel pleasure in their relations. Sexuality reflects the entire emotional expression of our experience, at the same time as it incorporates meaning influenced by the historical moment we are living ${ }^{(13)}$.

Sexuality is also presented here through a body women disclaim, as it is a sick body. Thus, the meanings we can attribute to our bodies and their sexual possibilities actually become a vital part of our individual constitution, no matter its social explanations ${ }^{(8)}$.

The next confection is the Pleasurable Woman - the woman who likes to feel pleasure. It is the hot woman who likes to have sexual intercourse. In this confection, sexuality looks at genitality, the man/woman relation in search of pleasure. This relation is part of hegemonic thinking about sexuality.

In the above confection, sexuality is reduced to genitality, to the sexual act, to reproduction, that is, to strictly biological components related to a merely organic need. This line of thinking is being constructed in western science, which has looked at the sexual act instead of sexuality. Subjective processes do not receive proper attention and research focuses on the medicalization of sex, that is, on the human body as a machine.

Western sexuality is shown as a product of a construction, control and as being spanned by knowledge production, initially characterized by information collection, by the construction of moral standards of behavior and knowledge about sexuality practices ${ }^{(14)}$.

In the 1890's, the founder of psychoanalysis elaborates a new sexuality concept, i.e. considered as a manifestation of childhood events that structures individual behavior across life ${ }^{(15)}$. It should be reminded that manifestations of sexuality are related with each person's psychic singularity. Hence, each subject is responsible for trying to respond to the enigma his/her own sexuality imposes - a response that is unique like every human being(3).

Another confection that emerged was The Meaning of the Penis - the meaning in view of HIV-positive status is marked by disgust. Disgust because it is the element that transports the virus inside the vagina, through sperm. So many feelings permeate the woman at first that she never wants to have a penis inside her again. It is hard to forgive! Mainly when the transmission occurs when the partner already knows that he has the virus. Moreover, some partners are prejudiced, believing that married women do not need to use a condom and that, if they do, it is a sign of betrayal.

This confection highlights disgust of the penis in a traumatic situation, i.e. HIV-positive status. The feeling of anguish is revealed when imaging the penetration of the penis into the woman's vagina, which brings the sperm with the virus. Genital inhibition is translated into the sexual life of a hysteric person instead of, as one might suppose, into indifference towards sexuality. In most cases, it is translated into aversion, true disgust of any carnal contact(16).

The final confection was Motherhood/HIV this confection refers to the feelings and sensations experienced during HIV-positive women's pregnancy. This moment is marked by profound feelings of doubts, fears and uncertainties. It is a trauma for a mother to know that her baby is at risk of being contaminated by her. Thus, the most disturbing feeling is the fear of transmission to the child.

These confections revealed a circumstance of profound anguish, as two contradictory moments live in the same scenario: life and death. Life appears in the child's conception, where the fear of contaminating one's child is marked by feelings of suffering. And, in this fear of transmission to one's child, uncertainties and the feeling of death also emerge. These two paradoxical perceptions, life and death, coexist in these pregnant women's unconscious, generating great anguish(11).

\section{Final considerations}

It could be observed that, at first, talking about sexuality with women living with HIV while using a group strategy aroused feelings of hesitation and expression difficulties, besides great emotion. However, the importance of this moment for some women was also perceived. This is an opportunity to try and express painful experiences that need to be signified.

In the group-researcher's production, sexuality appears in different dimensions: in the sexual act, in knowing one's own body, in professional accomplishment, in feelings of desire, love and disgust, in the relation with motherhood, among others. Hence, it is not limited to the sexual act but goes far beyond and appears as a symbolically constructed reality.

Through this study, we could perceive how sexuality is signified based on each person's experience. While sexuality is represented as something daily for some women living with HIV, which is part of their lives, for others, it is only part of healthy women's lives, and its experience is not allowed for women with HIV.

We consider that the importance of this kind of research among women with HIV/aids is mainly related to the fact that it allows these women to take hold of their own truths, constructing knowledge about their experiences that covers the subjective dimension, which is so often excluded in medical-scientific knowledge. 


\section{References}

1. Ministério da Saúde (BR). Manual de prevenção de Assistência e aconselhamento em HIV/AIDS para Profissionais de Saúde Mental. Brasília (DF): Ministério da Saúde; 2005.

2. Parker R, Galvão J. Quebrando o Silêncio - Mulheres e Aids no Brasil. Rio de Janeiro (RJ): Relume Dumará/Instituto de Medicina Social; 1996.

3. Ceccarelli PR. Sexualidade e preconceito. Rev Latinoam Psicopat Fund 2000; 3(3):18-37.

4. Silva AL, Ramos TRO. As Linhas Epistemológicas do Conhecimento Científico. [CD-ROM]. In: Organização da Associação Brasileira de Enfermagem. Anais do $11^{\circ}$ Seminário Nacional de Pesquisa em Enfermagem; 27-30 maio 2001. Belém (PA): ABEn-PA; 2001.

5. Gauthier JHM. Sociopoética: encontro entre arte, ciência e democracia na pesquisa em ciências humanas e sociais enfermagem e educação. Rio de janeiro: Editora Escola Ana Nery/UFRJ; 1999.

6. Silveira LC, Almeida ANS, Macedo SM, Alencar MN, Araújo MAM. A sociopoética como dispositivo para produção de conhecimento. Interface: comunicação, saúde e educação outubro-dezembro 2008; 12(27):875-83.

7. Freud S. Três Ensaios sobre a teoria da sexualidade (1905). In: Obras psicológicas completas de Sigmund Freud, v. 1. Rio de Janeiro: Imago; 1996.

8. Weeks J. O corpo e a sexualidade. In: Louro GL, organizador.
O corpo educado: pedagogias da sexualidade. 2. ed. Belo Horizonte: Autêntica; 2001. p. 35-82.

9. Freitas MRI, Gir E, Furegato ARF. Sexualidade do portador do vírus da imunodeficiência humana (HIV): um estudo com base na teoria da crise. Rev Latino-am Enfermagem janeiro-fevereiro 2002; 10(1):70-6.

10. Peres WS. Subjetividade e Cultura em Tempos de Aids. In: Carvalho MEG, Carvalhães FF, Cordeiro RP, organizadores. Cultura e subjetividade em tempos de aids. Londrina (PR): Associação Londrinense Interdisciplinar de Aids; 2005. p. 11-20.

11. Veras JF, Petracco MM. Adoecimento psíquico em mulheres portadoras do vírus HIV: um desafio para a clínica contemporânea. Psicol Ciênc Profissão 2007; 2(27):266-75.

12. Freud S. Nossa atitude para com a morte (1914-1916). In: Obras psicológicas completas de Sigmund Freud, v. 16. Rio de Janeiro: Imago; 1996.

13. Ressel LB, Silva MJP. Reflexões sobre a sexualidade velada no silêncio dos corpos. Rev Esc Enferm USP junho 2001; 35(2):150-4.

14. Foucault M. História da sexualidade: a vontade de saber. v. 1. $12^{\mathrm{a}}$ ed. Rio de Janeiro: Edições Graal; 1997.

15. Freud S. Três Ensaios sobre a teoria da sexualidade (19011905). In: Obras psicológicas completas de Sigmund Freud, v. 7. Rio de Janeiro: Imago; 1996.

16. Nasio J-D. A histeria: teoria clínica e psicanalítica. Rio de Janeiro: Jorge Zahar Editor; 1991.

Received: Mar. $19^{\text {th }} 2009$

Accepted: Sep. $3^{\text {rd }} 2009$ 